\title{
The first evidence of Acidithiobacillus albertensis in weathered ore samples from active gold mine Hodruša-Hámre (Slovakia)
}

\author{
Jana Sedláková-Kaduková ${ }^{1, \bigotimes}$, Jana Kisková $^{1}$, Lenka Maliničová ${ }^{1}$, Ivana Timková1, \\ Stanislav Jeleñ ${ }^{2}$ and Peter Pristaš ${ }^{1}$ \\ ${ }^{1}$ Department of Microbiology, Institute of Biology and Ecology, Faculty of Science, Pavol Jozef Šafarik University in Košice, \\ Šrobárova 2, SK-041 54 Košice, Slovak Republic \\ ${ }^{2}$ Earth Science Institute, Slovak Academy of Sciences, Ďumbierska 1, SK-974 01, Banská Bystrica, Slovak Republic
}

\section{Article info}

Article history:

Received: $28^{\text {th }}$ February 2019

Accepted: $5^{\text {th }}$ May 2019

\section{Keywords:}

Autotrophic bacteria

Acidithiobacillus albertensis

Gold mine

\begin{abstract}
Sulphur-oxidising autotrophic bacterial communities in deep biosphere from weathered ore samples from active gold mine Hodruša-Hámre, Slovakia were analysed using cultivation approach followed by DNA extraction, PCR amplification and 16S rRNA gene analyses. Indirect measurement of $\mathrm{pH}$ changes in cultivation media evidenced the presence of acidophilic bacteria with active production of acids. The decrease of $\mathrm{pH}$ was observed at the beginning of isolation and later $\mathrm{pH}$ in range of $1.5-2$ was maintained in both, sulphuric acid and thiosulphate, media. The presence of homogenous population of gram-negative rods was proved by Gram staining. Molecular analyses have revealed that the population of sulphur-oxidising bacteria in gold mine is dominated by a single species of Aciditiobacillus genus, identified as A. albertensis, suggesting the low level of autotrophic bacteria diversity in deep deposits. For the first time this species was isolated from weathered rocks of a gold mine subsurface environment.
\end{abstract}

\section{Introduction}

In the past years, our perspective on the Earth's biosphere has expanded from just the terrestrial and oceanic realms to include deep subterranean and subseafloor environments (Inagaki et al. 2003). The deep terrestrial subsurface environments such as those exemplified by deep mines represent an emerging area for exploring microbial populations with bewildering arrays of metabolic capabilities (Rastogi et al. 2010). Majority of these environments are characterised as extreme because of their hostile life conditions such as extreme temperature, $\mathrm{pH}$, pressure, low oxygen content, no light and toxic metals presence. The existence of microorganisms in such environment is of increasing scientific and practical interest because subsurface microorganisms with novel metabolic properties may be of potential value to industry for applications in bioremediation and biotechnology (Takai et al. 2001). Microbes in the deep terrestrial subsurface environment are considered to play a key role in deposition and weathering the minerals being a part of geochemical processes and are the only life forms that have been encountered in the deeper regions of the Earth's crust (Li et al. 2017).

Microbial communities existing in deep subsurface soil especially in gold mines have been studied very rarely and therefore they remain largely uncharacterized. The Banská Hodruša $\mathrm{Au}+\mathrm{Ag}, \mathrm{Pb}$, $\mathrm{Zn}, \mathrm{Cu}$ deposit at the Rozália mine $\left(48^{\circ} 27^{\prime} \mathrm{N}\right.$, 
$\left.18^{\circ} 51^{\prime} \mathrm{E}\right)$ is the last operating gold mine in Slovakia and it offers a unique opportunity for direct exploration of the mining-impacted deep subsurface environment. It occurs in the central zone of the large Middle Miocene Banská Štiavnica stratovolcano $(15.0-10.7$ mil. years $)$ within the Banská Štiavnica - Hodruša ore district, which belongs to the largest ore districts in the Carpathian arc, famous for $\mathrm{Ag}-\mathrm{Au}$ mining since the Middle Ages. The subhorizontal vein system occurs in $400-650 \mathrm{~m}$ depth, it is about $1.2 \mathrm{~km}$ long, hosted by andesite, near to the flat roof of the premineralization subvolcanic granodiorite pluton. The deposit consists of two parts, separated by a thick sill of quartz-diorite porphyry. The eastern part is currently mined, and the western part has already been depleted (Kubač et al. 2018; Koděra et al. 2018).

Gold-sulphide ore from epithermal vein deposit Banská Hodruša consists of gold, electrum, galena, sphalerite, chalcopyrite, and pyrite. Minor amounts of tellurides are present in the form of hessite, petzite and other rare $\mathrm{Au}$ sulphides and tellurides. Gangue minerals are represented by abundant quartz and adularia, clay minerals and carbonates. The ore has excellent metallurgical properties, content of gold is in range of $5-600$ g.t $\mathrm{t}^{-1}$, with average $20-30$ g.t $\mathrm{t}^{-1}$ and maximum achievable gold recovery by flotation is $96-98 \%$ (Chovan et al. 2016).

Microbial diversity present in Hodruša-Hámre mine have not been reported yet. In the present study our objective was to elucidate the existence and composition of sulphur-oxidising autotrophic bacterial population in the weathered ore samples of Hodruša-Hámre gold mine, Slovakia, by culturebased molecular methods. Sulphur oxidising TS strain of Acidithiobacillus albertensis species was isolated for the first time in Europe and basic microbiological characteristics and phylogenetic relatedness of the strain were determined.

\section{Experimental}

\section{Sample collection}

The samples (500 g each) were collected along the junction of the drift wall and the floor in vein Blanka. Yellow mats were covering the rock surface around the sample colleting site. The area was not disturbed by any type of activities including human trafficking from the end of 2000. The weathered ore was collected $10 \mathrm{~cm}$ below the surface with sterile spatula. The temperature at the time of sampling was $19^{\circ} \mathrm{C}$, it was measured using VWR EU 620-1259 thermometer. The samples were transported to the laboratory in sterile zip lock sacks on ice and in refrigerator.

\section{Isolation of autotrophic bacteria}

Six grams of homogenized soil sample was resuspended into $100 \mathrm{~mL}$ of sulphuric acid with pH 1.5 and $100 \mathrm{~mL}$ of thiosulphate medium. The composition of thiosulphate medium was $90 \mathrm{~mL}$ of mineral medium and $10 \mathrm{~mL}$ of $10 \%(\mathrm{w} / \mathrm{v})$ $\mathrm{Na}_{2} \mathrm{~S}_{2} \mathrm{O}_{3}$, mineral medium was composed of $1.2 \mathrm{~g}$ $\mathrm{KH}_{2} \mathrm{PO}_{4}, 0.2$ g K $\mathrm{K}_{2} \mathrm{HPO}_{4}, 0.75 \mathrm{~g} \mathrm{MgCl}_{2} \cdot 6 \mathrm{H}_{2} \mathrm{O}$, $0.15 \mathrm{~g} \mathrm{CaCl}_{2} \cdot 2 \mathrm{H}_{2} \mathrm{O}, 0.5 \mathrm{~g} \mathrm{NH}_{4} \mathrm{Cl}, 0.5 \mathrm{~g} \mathrm{Na}_{2} \mathrm{CO}_{3}$ into $1,000 \mathrm{~mL}$ of deionised water. Few drops of concentrated $\mathrm{HCl}$ were added into sterilised mineral media to dissolve precipitates. Both cultures were cultivated aerobically at $25{ }^{\circ} \mathrm{C}$ and $\mathrm{pH}$ values of media were measured once a week for $237 \mathrm{~d}$ using VWR pH $110 \mathrm{pH}$ meter Fresh medium $(20 \mathrm{~mL})$ was added into culture flask after $29 \mathrm{~d}$ of cultivation.

\section{DNA isolation, 16S rRNA gene amplification, RFLP analysis and sequence analysis}

Genomic DNA was extracted from bacterial cultures as described by Chen et al. (2009). Amplification of $16 \mathrm{~S}$ rDNA gene was performed using fD1 (5'-AGAGTTTGATCCTGGCTCAG-3') and rP2 (5'-ACGGCTACCTTGTTACGACTT-3') universal bacterial primers according to Vandžurová et al. (2013). The amplification products $(0.5 \mu \mathrm{g}$ of DNA) were analysed by restriction fragment length polymorphism (RFLP) method using AluI, HpaII, HaeIII, HhaI, EcoRI, and PstI (Thermo Scientific, USA) restriction endonucleases according to the manufacturer's instruction. The restriction fragments were separated by electrophoresis in $1 \%$ (w/v) agarose gel.

The 16S rDNA amplicon of the culture from thiosulphate medium was cloned into the 
pTZ57R/T vector using an InsTAclone PCR Cloning Kit (Thermo Fisher Scientific, USA) following manufacturer's instructions. Recombinant plasmids were isolated with GenElute $^{\mathrm{TM}}$ Plasmid Miniprep Kit (Sigma-Aldrich, USA), checked on $1 \%(\mathrm{w} / \mathrm{v})$ agarose gel and purified using Wizard ${ }^{\circledR}$ SV Gel and PCR Clean-Up kit (Promega, USA). Sequencing was performed using Sanger dideoxy sequencing method using plasmid specific primers by GATC Biotech sequencing facility (GATC Biotech AG, Germany). Sequences from both primers were assembled in CAP3 Sequence Assembly Program (http://doua.prabi.fr/software/cap3) (Huang and Madan 1999) and submitted to the GenBank database under accession number MH796351.

The sequences were taxonomically classified using BLASTN analysis against a database of $16 \mathrm{~S}$ rDNA sequences of the type strains of bacteria and archaea (http://www.ncbi.nlm.nih.gov/blast) (Altschul et al. 1990). To elucidate phylogenetic relatedness of TS isolate the $16 \mathrm{~S}$ rRNA sequences of Acidithiobacillus spp. were downloaded from GenBank database and aligned using clustalW algorithm. The phylogenetic tree was constructed using Neighbor Joining method with 1000 bootstrap replicates. For all phylogenetic analyses MEGA software ver. 7 (Kumar et al. 2016) was used.

\section{Results and Discussion}

The presence and activity of sulphur-oxidizing bacteria in both media was indirectly observed by changes of the medium $\mathrm{pH}$ values (Fig. 1). In medium containing sulphuric acid only a slight increase of $\mathrm{pH}$ was observed, the $\mathrm{pH}$ value increased from 1.5 up to 2.6 at the $35^{\text {th }}$ day followed by the decrease to 1.6 later on. After that time no significant changes in $\mathrm{pH}$ were observed till the end of monitoring period at day 237. In thiosulphate medium with initial $\mathrm{pH} 4$ the significant decrease of $\mathrm{pH}$ was observed to 2.1 after $17^{\text {th }}$ days of cultivation followed by the decrease to 1.54 after $94 \mathrm{~d}$. This $\mathrm{pH}$ value remained unchanged until the end of the observation period. Values of $\mathrm{pH}$ from 5.8 to 6.4 were measured in control experiments without bacteria added so it is evident that bacterial activity was responsible for the $\mathrm{pH}$ decrease.

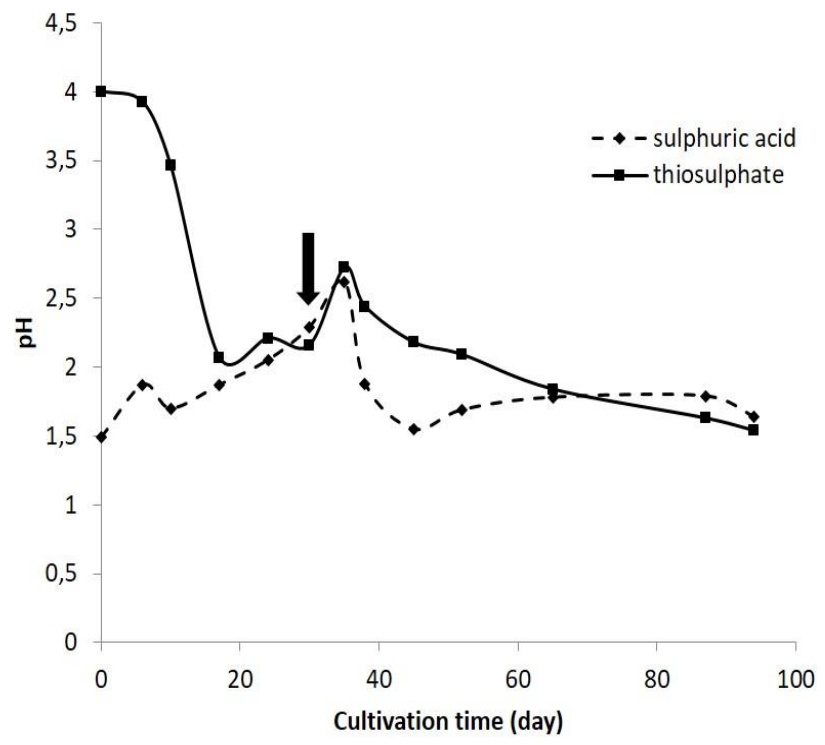

Fig. 1. Changes of $\mathrm{pH}$ during cultivation of bacteria from weathered ore samples from Hodruša-Hámre gold mine in two cultivation media (the arrow indicates the addition of $20 \mathrm{~mL}$ of fresh media into cultivation flasks at $29 \mathrm{~d}$ of cultivation).

Changes of $\mathrm{pH}$ in both cultivation media suggested acidifying activity of bacteria indirectly confirming presence of the bacteria. As no carbon source was added to the cultivation media bacterial growth and $\mathrm{pH}$ changes observed have to be accounted for the presence of autotrophic bacteria.

Under direct microscopic observation a morphologically homogenous population of small (approximately $1 \times 0.5 \mu \mathrm{m}$ ) gram-negative rods were observed only in thiosulphate medium (Fig. 2).

Bacterial DNA was, however, isolated from both media. RFLP analysis of the amplified 16S rRNA gene revealed that the identical RFLP banding pattern were generated for both, $\mathrm{H}_{2} \mathrm{SO}_{4}$ and thiosulphate media (data not shown). Lack of diversity observed in this experiment indicated the presence of highly genetic related autotrophic sulphur-oxidising bacteria in both media. The culture growing in thiosulphate medium designated as TS strain was used for further analyses. No heterotrophic growth of TS strain on LB medium with added glucose nor iron oxidation activity on $9 \mathrm{~K}$ medium (Silverman et al. 1959) were observed. The amplification and sequence analysis of 16S rRNA gene was used for molecular identification of TS isolate. Analysis of obtained 16S rRNA sequence against the prokaryotic_16S_ribosomal_RNA database 


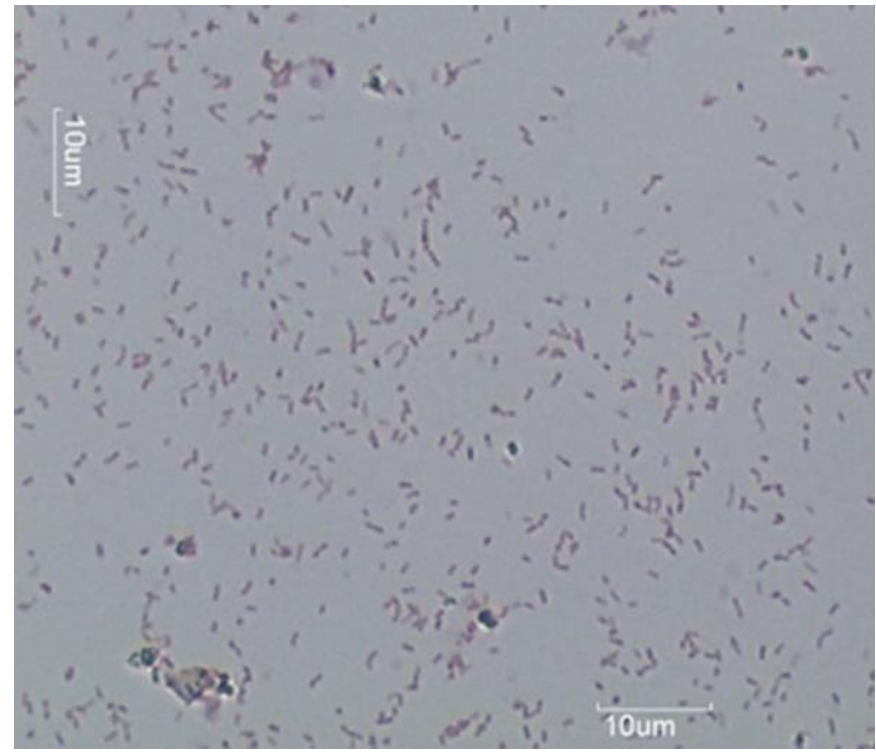

Fig. 2. Bright field photomicrograph of Gram-stained A. albertensis TS isolate growing in thiosulphate medium (magnification 640x). The image was taken using Motic BA310 microscope with digital camera attached. Scale bar $10 \mu \mathrm{m}$.

available at NCBI site (http://www.ncbi.nlm.nih.gov/blast) showed that 16S rRNA sequence of TS isolate is highly similar to the $16 \mathrm{~S}$ rRNA sequences of multiple
Acidithiobacillus spp. with highest similarity to the A. albertensis DSM 14366/ATCC 35403 strain with similarity as high as $99.7 \%$. Similarity to other well established species of Acidithiobacillus genus were lower e.g. A. thiooxidans $(98.7 \%)$, A. ferrooxidans $(97.7 \%)$ or A. ferridurans (97.6\%), respectively. Multiple sequence alignment placed 16S rRNA sequence of TS isolate to the large well supported clade (bootstrap support 100, see Fig. 3) of A. albertensis sequences. Based on the morphological, metabolic and phylogenetic analyses the autotrophic sulphuroxidising TS isolate cultivated from weathered ore samples from active gold mine Hodruša-Hámre could be classified as A. albertensis.

The bacteria of Acidithiobacillus genus are Gramnegative obligatory acidophilic chemolithotrophic autotrophs capable of growth utilising inorganic sulphur compounds as sole energy source (Karavaiko et al. 2003). Due to increasing industrial and environmental impact of acidithiobacilli there is profound interest in biology, genetics, and genomics of these bacteria (Pristas et al. 2018). The genus comprises 7 species which occur world-wide in a range of natural

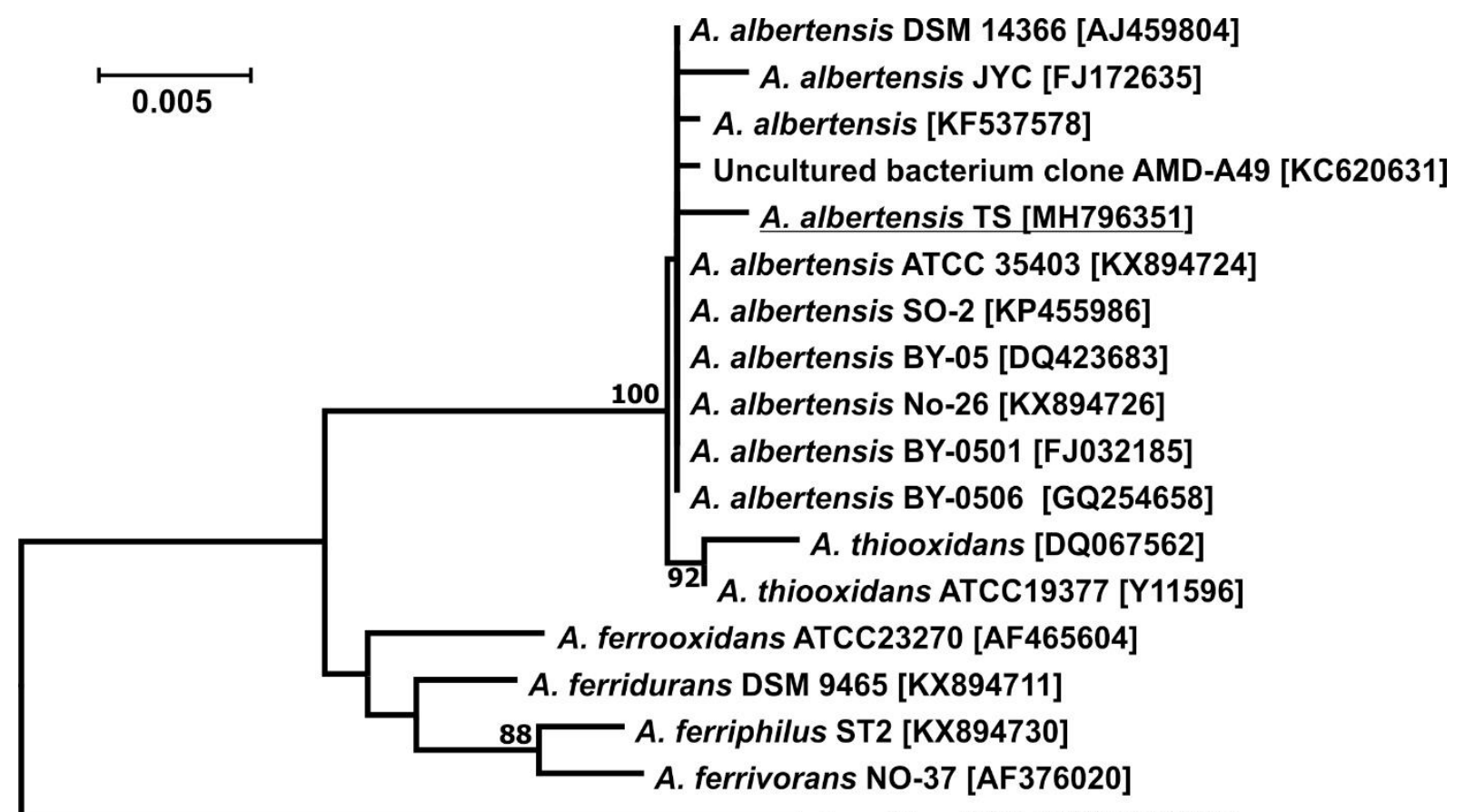

\section{A. caldus DSM 8584 [Z29975]}

Fig. 3. Unrooted phylogenetic tree documenting relatedness of A. albertensis TS isolate (underlined) to other Acidithiobacillus spp. 16S rRNA gene sequences. GenBank accession numbers are shown in parentheses. The tree was constructed using Neighbor Joining algorithm implemented in MEGA software ver. 7 (Kumar et al. 2016). Number at nodes are bootstrap values after 1000 repetition, only values over 80 are shown. 
Table 1. List of Acidithiobacillus sp. isolated from European mines (modified from Nuñez et al. 2017). Data on A. albertensis characterised in our study are shown bold.

\begin{tabular}{|c|c|c|c|}
\hline Country & Species & $\begin{array}{l}\text { Sample } \\
\text { Type } \\
\end{array}$ & Ore Type \\
\hline Austria & A. ferrooxidans & water & uranium \\
\hline \multirow{2}{*}{ Finland } & A. ferriphilus & NA & zinc \\
\hline & A. ferrooxidans & NA & copper \\
\hline \multirow{2}{*}{ France } & A. ferridurans & water & zinc, lead \\
\hline & A. ferrooxidans & water & zinc, lead \\
\hline \multirow{6}{*}{ Germany } & A. ferrooxidans & NA & uranium \\
\hline & A. ferrooxidans & soil & NA \\
\hline & A. ferrooxidans & water & copper \\
\hline & A. ferrooxidans & slurry & copper \\
\hline & A. ferrooxidans & soil & coal \\
\hline & A. ferrooxidans & soil & uranium \\
\hline Norway & A. ferrivorans & water & copper \\
\hline \multirow{2}{*}{ Romania } & A. ferrooxidans & soil & sulphide \\
\hline & A. ferrooxidans & soil & zinc \\
\hline \multirow{2}{*}{ Slovakia } & A. ferrooxidans & water & copper \\
\hline & A. albertensis & soil & gold \\
\hline \multirow{2}{*}{ Spain } & A. ferrooxidans & water & nickel \\
\hline & A. ferrivorans & soil & copper \\
\hline \multirow{6}{*}{$\begin{array}{l}\text { United } \\
\text { Kingdom }\end{array}$} & A. caldus & soil & coal \\
\hline & A. ferrooxidans & soil & coal \\
\hline & A. ferrooxidans & soil & copper \\
\hline & A. ferrooxidans & water & $\operatorname{tin}$ \\
\hline & A. ferrooxidans & NA & pyrite \\
\hline & A. thiooxidans & soil & coal \\
\hline
\end{tabular}

and industrial settings (Kelly and Wood 2000), six members of the genus, except A. albertensis, were already isolated in European industrial areas (Table 1).

Although A. albertensis species was for the first time described by Bryant et al. already in 1983 (Bryant et al. 1983), it is not frequently studied species and there are very limited number of strains available, mainly from China territory (Liu et al. 2008). In previous studies this species was isolated from acidic soil adjacent to a sulphur stockpile in Canada (Bryant et al. 1983), from acid-mine drainage of copper ore rich of sulphur in China (Xia et al. 2007), from copper ore sludge in China mine (Xingyu et al. 2010), from acidic river Rio Agrio in Argentina (Urbieta et al. 2012) and from operating zinc sulphide heap processing the ore from Red Dog Mine in Alaska (Lizama et al.
2012). For the first time A. albertensis bacterium was isolated from gold mine subsurface environment and it is for the first time when this bacterium was isolated from Europe territory. Preliminary report on TS isolate characterization appeared in Pristas et al. (2018). TS isolate of $A$. albertensis, characterised in our study, shows typical features of the species. It is acidophilic, mesophilic, obligatory chemoautotrophic, aerobic, gram-negative rods, not producing spores. The strain is unable neither to grow heterotrophically nor to catalyse the dissimilatory oxidation of ferrous iron. The sequence analysis placed 16S rRNA sequence of TS isolate to the large cluster of $A$. albertensis sequences with similarity values as high as $99.7 \%$. To the cluster some environmental sequences fall as well (uncultured bacterium clone AMD-A49, GenBank accession No. KC620631) from acid mine drainage sample in China. The sequence comparison confirmed close relationship of A. albertensis and A. thiooxidans species (Fig. 3) forming a cluster well separated from ferrous ions oxidizers.

The BY-05 strain of $A$. albertensis was employed for bioleaching of metal sulphides ores (Xia et al. 2007) so probably biotechnological utilisation of the species might be oriented more to sulphur dissolution or as a part of bioleaching consortium with iron-oxidising bacteria to metal dissolution.

\section{Conclusions}

The subsurface biosphere in gold deposits was very rarely studied, however, according to the newest findings become evident that bacteria actively contribute and regulate biogeochemical cycles in this environment. The diversity of culturable microorganisms involved in sulphur oxidation was investigated in the weathered rocks of gold mine Hodruša-Hámre, Slovakia. Just the single species of Acidithiobacillus albertensis was isolated from the samples suggesting the low level of biodiversity of autotrophic bacteria in deep subsurface deposits. In this study we for the first time reported autotrophic bacterial diversity and isolation of A. albertensis from solid sample of weathered rocks in deep gold mine. Although A. albertensis is not an unknown species, there is still very little known about these bacteria and their potential 
in bioleaching of metals from ores or metal-bearing waste. Further studies of functional bacteria and potential new functional species need to be carried out to explore their specific contributions to gold biogeochemical cycling.

\section{Acknowledgement}

The work was financially supported by Research Agency of the Ministry of Education, Science, Research and Sport of Slovak Republic under the VEGA Projects 1/0229/17 and SK-PL-18-0012. SJ acknowledges support from VEGA Project 1/0560/15 and APVV-15-0083 project from Slovak Research and Development Agency.

\section{Conflict of Interest}

The authors declare that they have no conflict of interest.

\section{References}

Altschul SF, Gish W, Miller W, Myers EW, Lipman DJ (1990) Basic local alignment search tool. J. Mol. Biol. 215: 403-410.

Bryant RD, McGroarty KM, Costerton JW, Laishley EJ (1983) Isolation and characterization of a new acidophilic Thiobacillus species (T. albertis). Can. J. Microbiol. 29: 1159-1170.

Chen H, Yang B, Chen X (2009) Identification and characterization of four strains of Acidithiobacillus ferooxidans isolated from different sites in China. Microbiol. Res. 164: 613-623.

Chovan M, Jágerský I, Delaney V, Žitňan P, Kubač A, Bačík P, Troppová D, Mikuš T (2016) Mineralogy of ore dressing products from Banská Hodruša $\mathrm{Au}(\mathrm{Ag}, \mathrm{Pb}$, $\mathrm{Cu}$ ) epithermal deposit. Acta Geol. Slov. 8: 203-216.

Huang X, Madan A (1999) CAP3: A DNA sequence assembly program. Genome Res. 9: 868-877.

Inagaki F, Takai K, Hirayame $\mathrm{H}$, Yamato $\mathrm{Y}$, Nealson $\mathrm{KH}$, Horikoshi K (2003) Distribution and phylogenetic diversity of the subsurface microbial community in a Japanese epithermal gold mine. Extremophiles 7: 307-317.

Karavaiko GI, Turova TP, Kondrat'eva TF, Lysenko AM, Kolganova TV, Ageeva SN, Muntyan LN, Pivovarova TA (2003) Phylogenetic heterogenity of the species Acidithiobacillus ferrooxidans. Int. J. Syst. Evol. Micr. 53: 113-119.

Kelly DP, Wood AP (2000) Reclassification of some species of Thiobacillus to the newly designated genera Aciditihobacillus gen. nov., Halothiobacillus gen. nov. and Thermithiobacillus gen. nov. Int. J. Syst. Evol. Micr. 50: 511-516.

Koděra P, Kubač A, Vojtko R, Uhlík P, Lexa J, Chovan M (2018) Field stop 1: Hodruša - Hámre, Rozália gold mine. In Joint $5^{\text {th }}$ Central-European Mineralogical Conference and $7^{\text {th }}$ Mineral Sciences in the Carpathians Conference, Excursion Guide, Bačík P, Fridrichová J (Eds.), Banská Štiavnica, June 26-30, 2018, p.16-21.

Kubač A, Chovan M, Koděra P, Kyle RJ, Žitňan P, Lexa J, Vojtko R (2018) Mineralogy of the epithermal precious and base metal deposit Banská Hodruša at the Rozália Mine (Slovakia). Miner. Petrol. 112: 705-731.

Kumar S, Stecher G, Tamura K (2016) MEGA7: Molecular Evolutionary Genetics Analysis Version 7.0 for Bigger Datasets. Mol. Biol. Evol. 33: 1870-1874.

Li M, Tian H, Wang L, Duan J (2017) Bacterial Diversity in Linglong Gold Mine, China. Geomicrobiol. J. 34: 267-273.

Liu XY, Chen BW, Wen JK (2008) Dominance of Acidithiobacillus at ore surface of Zijinshan commercial low-grade copper bioleaching heap. Trans. Nonferrous Met. Soc. China. 18: 1506-1512.

Lizama HM, Jensen SE, Stradling AW (2012) Dynamic microbial populations in heap leaching of zinc sulphide ore. Min. Eng. 25: 54-58.

Nuñez H, Moya-Beltrán A, Covarrubias PC, Issotta F, Cárdenas JP, González M, Atavales J, Acuña LG, Johnson DB, Quatrini R (2017) Molecular systematics of the genus Acidithiobacillus: insights into the phylogenetic structure and diversification of the taxon. Front. Microbiol. 8: 30.

Pristas P, Kiskova J, Timkova I, Malinicova L, Luptakova A, Kusnierova M, Sedlakova-Kadukova J (2018) Genetic variability in Acidithiobacillus spp. - a working horse of environmental biotechnologies. Nova Biotechnol. Chim. 17: 125-131.

Rastogi G, Osman S, Kukkadapu R, Engelhard M, Vaishampayan PA, Andersen GL, Sani RK (2010) Microbial and mineralogical characterizations of soils collected from the deep biosphere of the former Homestake Gold Mine, South Dakota. Microb. Ecol. 60: 539-550.

Silverman MP, Lundgren DG (1959) Studies on the chemoautotrophic iron bacterium Ferrobacillus ferrooxidans. I. An improved medium and a harvesting procedure for securing high cell yields. J. Bacteriol. 77: 642-647.

Takai K, Moser DP, Onstott TC, Spoelstra N, Pfiffner SM, Dohnalkova A, Fredrickson JK (2001) Alkaliphilus transvaalensis gen. nov., sp. nov., an extremely alkaliphilic bacterium isolated from a deep South African gold mine. Int. J. Syst. Evol. Micr. 51: 12451256.

Urbieta MS, Toril EG, Aguilera A, Giaveno MA, Donati E (2012) First prokaryotic biodiversity assessment using molecular techniques of an acidic river in Neuquén, Argentina. Microb. Ecol. 64: 91-104.

Vandžurová A, Bačkor P, Javorský P, Pristaš P (2013) Staphylococcus nepalensis in the guano of bats (Mammalia). Vet. Microbiol. 164: 116-121.

Xia JJ, Peng AA, He H, Yang Y, Liu XD, Qiu GZ (2007) A new strain Acidithiobacillus albertensis BY-05 for bioleaching of metal sulfides ores. Trans. Nonferrous Met. Soc. China. 17: 168-175. 
Nova Biotechnol Chim (2019) 18(1): 18-24

Xingyu L, Bowei Ch, Jiankang W, Renman R (2010) Leptospirillum forms a minor portion of the population in Zijinshan commercial non-aeration copper bioleaching heap identified by $16 \mathrm{~S}$ rRNA clone libraries and real-time PCR. Hydrometallurgy 104: 399-403. 